\title{
PENDEKATAN VALUASI EKONOMI UNTUK MENGHITUNG DAMPAK EKONOMI AKIBAT TUMPAHAN MINYAK DI WILAYAH PESISIR DAN LAUT
}

\section{Economic Valuation Approach for Calculating the Economic Impact Due to Oil Spill on Coastal and Marine}

\author{
*Andrian Ramadhan, Siti Hajar Suryawati dan Sonny Koeshendrajana \\ Balai Besar Riset Sosial Ekonomi Kelautan dan Perikanan \\ Gedung Balitbang KP I Lt. 4 \\ Jalan Pasir Putih Nomor 1 Ancol Timur, Jakarta Utara, Indonesia \\ Telp: (021) 64711583 Fax: 64700924 \\ Diterima tanggal: 14 April 2017 Diterima setelah perbaikan: 29 April 2017 \\ Disetujui terbit: 6 Juni 2017 \\ "email: iansosek30@yahoo.com
}

\begin{abstract}
ABSTRAK
Kejadian tumpahan minyak di laut bisa terjadi sewaktu-waktu dan dimana saja khususnya yang memiliki kedekatan dengan jalur perkapalan dan aktivitas pengeboran minyak. Hal ini menuntut kewaspadaan pemerintah sekaligus kemampuan untuk menanggulangi kejadian yang terjadi secara cepat. Seiring dengan itu, pemerintah juga harus segera dapat menghitung nilai kerugian atau dampak ekonomi yang ditimbulkan. Penelitian ini bertujuan untuk menyusun pedoman perhitungan dampak kerugian akibat tumpahan minyak dengan pendekatan valuasi ekonomi. Penilaian dengan pendekatan ini memberi keuntungan yaitu terhitungnya seluruh manfaat barang dan jasa yang hilang baik yang bersifat ekonomi langsung, ekologi maupun sosial budaya. Secara total nilai dampak ekonomi dihitung dengan memasukkan tiga komponen yaitu biaya kerugian ekonomi yang dikompensasi, biaya rehabilitasi dan biaya administrasi penghitungan kerugian.
\end{abstract}

Kata Kunci: tumpahan minyak, valuasi ekonomi, kerugian ekonomi, pesisir dan laut, kompensasi

\section{ABSTRACT}

Oil spills in the sea water can occur at anytime and anywhere especially on sites are closely associated with shipping and oil drilling activities. This issue requires government vigilance and ability in order to cope with it responsively. The government must also be able to calculate the economic loss. The purpose of this research is to compose a guidance of economic valuation for oil spill economic impact. The use of economic valuation give advantages where the loss of all benefits of goods and services, that include economic, ecological and socio-cultural value, are comprehensively counted. In total, the economic impact is calculated based on three components: the cost of compensated economic losses, rehabilitation costs and administrative costs of calculating losses.

Keywords: oil spill, economic valuation, economic loss, coastal and marine, compensation

\section{PENDAHULUAN}

Indonesia merupakan negara kepulauan dengan jumlah pulau 13.466, luas daratan $1.922 .570 \mathrm{~km}^{2}$ dan luas perairan 3.257 .483 $\mathrm{km}^{2}$ (Badan Informasi Geospasial (BIG), 2014). Perairan Indonesia merupakan jalur transportasi yang strategis sebagai lalu lintas kapal-kapal barang dimana dilintasi sekurangnya $70 \%$ angkutan barang melalui laut dari Eropa, Timur Tengah dan Asia Selatan ke wilayah Pasifik, dan sebaliknya (Pardosi, 2016). Posisi strategis ini, selain menguntungkan juga mengandung resiko berupa dampak negatif dari kemungkinan terjadinya tumpahan minyak. Beberapa contoh kasus yang pernah terjadi diantaranya adalah tumpahan minyak dari kecelakaan Kapal Choya Maru di Buleleng Bali pada tahun 1979, tabrakan Kapal Orapin Global dengan kapal tanker Evoikos di selat Singapura tahun 1997, dan meledaknya kapal MV Fu Yuan Fu F66 di Teluk Ambon tahun 2005 (JICA-Dephub, 2002; Helut, 2005). Berdasarkan catatan statistik, 
kejadian tumpahan minyak terbesar tercatat pada tahun 2005 dimana pada sektor hulu minyak tertumpah sebesar 9.350 barrel dan pada sektor hilir sebesar 5.000 barel (Kementerian Energi dan Sumberdaya Mineral (KESDM), 2016).

Tumpahan minyak selain dari kapal tanker juga dapat disebabkan oleh aktivitas pengeboran lepas pantai yang ada. Sebagaimana diketahui bahwa di Indonesia terdapat ratusan pengeboran lepas pantai. Bahkan kecenderungan penemuan minyak lepas pantai baru $70 \%$ ditemukan pada daerah lepas pantai dan laut dalam (Lubis, 2010). Salah satu contoh dan masih menyisakan persoalan sampai dengan saat ini adalah kasus tumpahan minyak Montara di perairan Laut Timor yang terjadi pada tahun 2009.

Dari seluruh perairan Indonesia, wilayah yang rentan terhadap pencemaran akibat tumpahan minyak dari kedua sumber utama pencemaran di atas adalah Selat Malaka, Pantai Selatan Jawa (Samudera Hindia), Selat Lombok, dan Selat Makasar. Hal ini tidak terlepas dari penggunaan perairan tersebut baik sebagai jalur lintas kapal tanker maupun sebagai daerah produksi. Mengingat kondisi yang rawan tersebut pemerintah Indonesia berkewajiban mengembangkan suatu kebijakan dan mekanisme yang memungkinkan dilakukannya tindakan secara cepat, tepat dan terkoordinasi dalam penanggulangan tumpahan minyak di laut dan dampak lingkungan yang mungkin terjadi. Salah satunya dengan mengetahui nilai sumberdaya yang tercemar, sehingga pada saat terjadi tumpahan minyak dapat mengajukan klaim ganti rugi terutama untuk kegiatan pemulihan lingkungan perairan yang terkena dampak tumpahan minyak. Atas dasar itu penelitian ini dilakukan dengan tujuan menyusun pedoman perhitungan dampak kerugian akibat tumpahan minyak dengan pendekatan valuasi ekonomi.

\section{METODOLOGI}

\section{Waktu dan Lokasi Penelitian}

Penelitian dilaksanakan pada bulan September 2016. Lokasi penelitian bersifat desk study yang dilakukan di Jakarta.

\section{Data dan Sumber Data}

Data yang digunakan adalah data sekunder. Data sekunder diperoleh melalui, penelusuran pustaka (desk study) berupa dokumen, literatur maupun laporan-laporan penelitian sebelumnya yang relevan dan terkait dengan topik penelitian.

\section{Metode Analisis Data}

Metode penelitian merupakan suatu cara agar data dapat diperoleh dan dianalisis menurut suatu tujuan tertentu. Data yang terkumpul kemudian dianalisis dengan teknik analisis isi (content analysis). Analisis isi merupakan teknik yang dapat menyajikan data secara obyektif, sistematis dan deskripsi kuantitatif dari suatu konten. Teknik ini juga membuat peneliti dapat melakukan suatu test terhadap teori dalam rangka memahami suatu data (Elo \& Kyngas, 2007). Pada analisis isi konteks dari suatu dokumen, artikel, atau buku diperhatikan sehingga tersaji dalam suatu paparan yang jelas.

\section{HASIL DAN PEMBAHASAN}

\section{Konsep Valuasi Ekonomi Dalam Penilaian Dampak Ekonomi Akibat Tumpahan Minyak}

Tumpahan minyak menurut definisi dalam pasal 1 Peraturan Presiden (Perpres) Nomor 109 Tahun 2006 tentang Penanggulangan Keadaan Darurat Tumpahan Minyak di Laut, adalah lepasnya minyak baik langsung atau tidak langsung ke lingkungan lautyang berasal darikegiatan pelayaran, kegiatan pengusahaan minyak dan gas bumi atau kegiatan lain. Kondisi ini dapat menyebabkan terjadinya pencemaran laut yang menganggu ekosistem dan biota yang hidup didalamnya. Definisi pencemaran laut yaitu perubahan pada lingkungan laut yang terjadi sebagai akibat adanya aktivitas manusia sehingga masuk material ke dalam lingkungan laut yang menyebabkan efek merugikan terhadap sumberdaya hayati, membahayakan terhadap kesehatan manusia, menurunnya kualitas lingkungan laut, pemukiman serta tempat rekreasi (United Nation (UN), 1982).

Penghitungan dampak tumpahan minyak dan nilai kerugiannya akan sangat tergantung dengan kuantitas dan intensitas volume minyak yang tertumpah. Pada wilayah laut dampak tumpahan minyak dapat menyebabkan sejumlah biota perairan penting seperti kelompok setasea terjebak dalam minyak. Meski secara jumlah relatif kecil potensi tersebut terjadi, namun memiliki biota yang terkena dampak memiliki arti penting. Bila jumlah tumpahan sangat tinggi, dampak tumpahan minyak dilaut berpengaruh pada kualitas perairan disekitarnya yang tentu juga akan mengganggu kehidupan biota didalamnya. Dampak yang lebih 
signifikan akan lebih terasa bila tumpahan minyak tersebut sampai pada wilayah-wilayah pesisir. Karena pada wilayah pesisir terdapat berbagai ekosistem penting dan berdampak langsung pada penurunan manfaat dan jasa dari ekosistem tersebut.

De Groot et al. (2002) menyebutkan beberapa fungsi ekosistem termasuk pesisir dalam beberapa kelompok, yaitu: (1) Fungsi Regulasi dimana ekosistem mampu mengatur proses ekologi yang penting di alam; (2) Fungsi Habitat dimana ekosistem adalah rumah atau tempat hidup bagi tumbuhan maupun hewan; (3) Fungsi Produksi dimana ekosistem melakukan fotosintesis untuk menkonversi nutrien menjadi energi dan selanjutnya dimakan oleh biomas hidup yang lain, dan; (4) Fungsi informasi dimana ekosistem memberikan fungsi acuan dan dapat sebagai sumber tempat untuk relaks, pengayaan kerohaniaan dan rekreasi. Fungsi dari ekosistem tersebut kemudian membentuk barang dan jasa yang menjadi manfaat dan bernilai ekonomi bagi manusia.

Barang dan jasa yang dihasilkan oleh lingkungan dapat diklasifikasikan menjadi 3, yaitu nilai ekologi, nilai sosial budaya dan nilai ekonomi.

\section{Nilai Ekologi}

Nilai ekologi dapat dilihat dari ekosistem utama yang ada di wilayah pesisir yakni ekosistem mangrove, ekosistem lamun dan ekosistem terumbu karang. Ekosistem hutan mangrove merupakan salah satu sumber daya alam wilayah pesisir yang mempunyai peranan penting ditinjau dari sudut sosial, ekonomi, dan ekologis. Fungsi utama hutan mangrove adalah sebagai penyeimbang ekosistem dan penyedia berbagai kebutuhan hidup bagi manusia dan mahluk hidup lainnya. Sumber daya hutan mangrove, selain dikenal memiliki potensi ekonomi sebagai penyedia sumber daya kayu juga sebagai tempat pemijahan (spawning ground), daerah asuhan (nursery ground), dan juga sebagai daerah untuk mencari makan (feeding ground) bagi ikan dan biota laut lainnya, juga berfungsi untuk menahan gelombang laut dan intrusi air laut ke arah darat (Bengen, 2004). Selain itu juga merupakan pemasok larva udang, ikan dan biota lainnya (Claridge \& Burnett,1993)

Begitu juga dengan ekosistem lamun dan ekosistem terumbu karang. Padang lamun (seagrass bed) yaitu hamparan vegetasi lamun yang menutup suatu area pesisir/laut dangkal, terbentuk dari satu jenis atau lebih dengan kerapatan padat atau jarang. Lamun umumnya membentuk padang lamun yang luas di dasar laut yang masih dapat dijangkau oleh cahaya matahari yang memadai bagi pertumbuhannya. Lamun hidup di perairan yang dangkal dan jernih, dengan sirkulasi air yang baik. Seperti halnya dengan ekosistem mangrove, secara ekologis padang lamun mempunyai beberapa fungsi penting bagi wilayah pesisir, yaitu: (a) produsen detritus dan zat hara; (b) mengikat sedimen dan menstabilkan substrat yang lunak, dengan sistem perakaran yang padat dan saling menyilang; (c) sebagai tempat berlindung, mencari makan, tumbuh besar, dan memijah bagi beberapa jenis biota laut, terutama

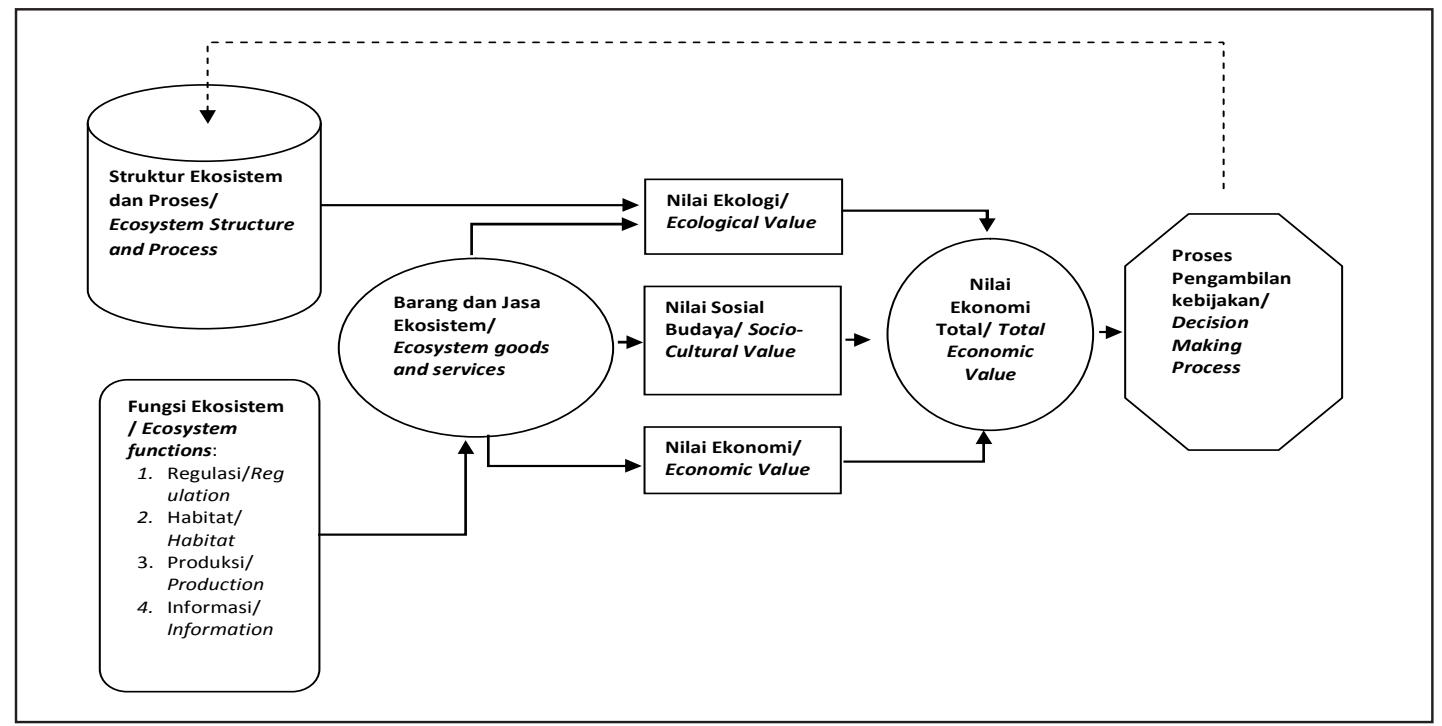

Gambar 1. Kerangka Terpadu Valuasi Fungsi Ekosistem

Figure 1. Integrated Framework of Valuation Ecosystem Function

Sumber: De Groot et al. (2002)/Source: De Groot et al. (2002). 
yang melewati masa dewasanya di lingkungan ini, dan; (d) sebagai tudung pelindung yang melindungi penghuni padang lamun dari sengatan matahari.

Ke arah laut setelah ekosistem mangrove dan padang lamun, terdapat ekosistem terumbu karang. Secara ekologi, ekosistem terumbu karang berfungsi sebagai penyangga bagi kehidupan biota pesisir dan lautan, serta sebagai pelindung pantai dari abrasi akibat terpaan arus, angin dan gelombang.

\section{Nilai Sosial Budaya}

Interaksi yang terbentuk antara manusia dan alam juga membentuk nilai sosial budaya di masyarakat khususnya terkait persepsi masyarakat terhadap alam. Persepsi tersebut kemudian membentuk pengaturan sosial mengenai bagaimana seharusnya masyarakat memperlakukan sumber daya. Oleh karena itu penilaian sosial budaya umumnya melalui pendekatan persepsi terhadap sesuatu yang bernilai estetika, religi dan budaya. Akan tetapi nilai yang terbentuk pada realitasnya lebih dari sekedar itu, melainkan juga fenomena sosial yang terbentuk.

Fenomena sosial yang dimaksud adalah hubungan sosial dan peran kelembagaan lokal yang ada di masyarakat. Hubungan sosial pada masyarakat nelayan merupakan sebuah aksi kolektif yang tercipta secara evolutif sebagai sebuah reaksi atas keberadaan kondisi sumberdaya yang dinamis. Tindakan ini mampu menjadi suatu sistem jaminan ekonomi bagi masyarakat untuk dapat menjaga keberlangsungan penghidupannya. Oleh karenanya, melalui gambaran hubungan tersebut, ternilai fungsi keberadaan sumberdaya terhadap sebuah tatanan hubungan sosial dalam masyarakat dalam rangka menciptakan jaminan ekonomi (Koeshendrajana et al., 2015).

\section{Nilai Ekonomi}

Menurut Kay \& Alder (1999) pemanfaatan wilayah pesisir dapat dibagi ke dalam empat kategori yaitu untuk: (1) eksploitasi sumber daya; (2) infrastruktur; (3) kegiatan turistik dan rekreasi, dan; (4) serta konservasi dan perlindungan biodiversitas. Dari empat klasifikasi tersebut 3 diantaranya merupakan bentuk pemanfaatan yang memiliki nilai ekonomi secara langsung. Selain itu kita juga melihat bahwa wilayah pesisir dimanfaatkan untuk wilayah pemukiman masyarakat.
Eksploitasi sumber daya pada wilayah pesisir dapat dikaji berdasarkan tipe ekosistem yang ada yaitu, mangrove, lamun dan terumbu karang. Sumber daya pada ekosistem mangrove yang umum dieksploitasi pada ekosistem mangrove diantaranya adalah ikan, udang, kepiting, kerang, burung, kayu serta buah mangrove. Ikan dan udang dieksploitasi pada kolom perairan, sementara kepiting dan kerang pada substrat di sekitar kawasan mangrove (Bengen, 2004). Selain eksploitasi dengan cara mengambil langsung dari alam, wilayah ekosistem mangrove juga dilakukan kegiatan budi daya seperti budi daya ikan dan kepiting.

Ekosistem lamun menyimpan berbagai potensi ekonomi untuk dimanfaatkan oleh manusia, meski pemanfaatannya saat ini masih cukup terbatas. Beberapa manfaat yang sering dimanfaatkan adalah biota yang hidup berasosiasi dengan ekosistem ini seperti ikan, teripang dan kerang. Jenis-jenis tersebut sebagian dimanfaatkan untuk dikonsumsi secara langsung. Beberapa jenis teripang telah dimanfaatkan pula untuk kepentingan medis dan farmasi.

Ekosistem terumbu karang menyimpan berbagai sumber daya yang dapat dimanfaatkan secara ekonomi oleh manusia. Supriharyono (2007) menyatakan bahwa salah satu manfaat ekosistem terumbu karang adalah sebagai sumber makanan bagi manusia dimana ekosistem ini menyediakan berbagai organisme seperti ikan karang, penyu, udang barong, octopus, kerang, oyster dan rumput laut yang banyak dimanfaatkan oleh para nelayan, baik untuk dimakan sendiri maupun untuk dijual. Lebih dari itu, terumbu karang juga menyediakan berbagai bahan baku untuk keperluan industri kosmetik dan obat-obatan. Sebagaimana penelitian Faikoh et al. (2013) yang menunjukkan ekstrak kasar karang lunak Geodia sp. segar memiliki aktivitas antibakteri terhadap E. coli dan Vibrio parahaemolyticus.

\section{Metode Penilaian Dampak Ekonomi Akibat Tumpahan Minyak}

Penilaian dampak ekonomi akibat tumpahan minyak dapat didekati dengan berbagai pendekatan dimana salah satunya adalah pendekatan valuasi ekonomi. Pemilihan teknik valuasi disebabkan kemampuannya untuk melihat nilai ekonomi suatu kawasan secara komprehensif. Model de Groot (2002) misalnya mencakup seluruh barang dan jasa yang dihasilkan sumber daya mulai dari 
ekologi, ekonomi sampai sosial budaya. Konsep lain menggunakan total economic value (TEV) dalam melakukan valuasi ekonomi. Konsep ini pada dasarnya menilai semua yang tercakup dalam aset lingkungan yang dibagi menurut nilai manfaat atau bukan manfaat (manfaat pasif) (Pearce et al., 2006).

Valuasi ekonomi sumber daya berperan penting dalam menyediakan informasi untuk membantu proses pengambilan keputusan terkait dengan kebijakan publik (Fauzi, 2014). Nilai ekonomi total adalah nilai-nilai ekonomi yang terkandung dalam suatu sumber daya alam, baik nilai guna maupun nilai fungsional yang harus diperhitungkan dalam menyusun kebijakan pengelolaannya sehingga alokasi dan alternatif penggunaannya dapat ditentukan secara benar dan mengenai sasaran (Nilwan et al., 2003).

Penghitungan total nilai kerugian dampak tumpahan minyak terdiri dari 3 (tiga) komponen, yaitu Nilai Ganti Rugi / kompensasi (Compensable Value), Biaya Pemulihan (Restoration Cost) dan Biaya Penilaian (Assesment Cost) (Ofiara \& Seneca, 2001).

\section{a. Nilai Ganti Rugi/Kompensasi (Compensable Value)}

Nilai Ganti Rugi / Kompensasi merupakan segala sesuatu yang diterima dapat berupa fisik maupun non fisik dan harus dihitung dan diberikan kepada pihak atau seseorang yang umumnya merupakan objek yang terkena dampak tumpahan minyak. Compensable value ini terdiri dari beberapa nilai yang berbasis pada jenis pemanfaatan dan pemanfaat SDKP pada wilayah yang terkena dampak tumpahan minyak. Nilai-nilai tersebut terdiri dari :

1. Nilai ekonomi yang hilang dari aktivitas Penangkapan Ikan (ekosistem terumbu karang, mangrove dan laut);

2. Nilai ekonomi yang hilang dari aktivitas budi daya (darat, payau dan laut);

3. Nilai ekonomi yang hilang dari aktivitas wisata bahari;

4. Nilai ekonomi dari kerusakan ekosistem pesisir (mangrove, terumbu karang dan lamun);

5. Nilai ekonomi yang hilang dari aktivitas pengolahan perikanan;

6. Nilai ekonomi yang hilang dari terganggunya estetika lingkungan pesisir;

7. Nilai ekonomi yang hilang dari kerusakan alat produksi penangkapan (kapal, alat tangkap, dan alat bantu penangkapan);

8. Nilai ekonomi yang hilang dari kerusakan sarana produksi budi daya (keramba, tambak dan lainnya);

9. Nilai ekonomi yang hilang dari kerusakan sarana dan prasarana wisata bahari;

Masing-masing nilai ekonomi dihitung dengan menggunakan pendekatan teknik penghitungan yang berbeda-beda sesuai dengan karakteristik pemanfaat dan ekosistemnya. Adapun teknik penghitungan pada nilai-nilai tersebut dapat dilihat pada Tabel 1.

Tabel 1. Jenis Nilai Ekonomi yang Hilang di Wilayah Pesisir Sebagai Akibat Tumpahan Minyak. Table 1. Type of Economic Value Lost in the Coastal Area as a Result of Oil Spill.

\begin{tabular}{|c|c|c|}
\hline No & $\begin{array}{l}\text { Jenis Nilai Ekonomi yang Hilang/ } \\
\text { Economics Loss }\end{array}$ & $\begin{array}{l}\text { Teknik Analisis Datal } \\
\text { Technique of Data Analysis }\end{array}$ \\
\hline 1. & $\begin{array}{l}\text { Nilai ekonomi yang hilang dari aktivitas Penangkapan } \\
\text { Ikan (ekosistem terumbu karang, mangrove dan laut)/ } \\
\text { The economic value lost from fishing activities (coral } \\
\text { reef, mangrove and marine ecosystems) }\end{array}$ & $\begin{array}{l}\text { Effect on Production (Income Approach, } \\
\text { Residual Rent) / Cost Benefit Analysis / } \\
\text { Bio Ekonomi }\end{array}$ \\
\hline 2. & $\begin{array}{l}\text { Nilai ekonomi yang hilang dari aktivitas budi daya } \\
\text { (darat, payau dan laut)/ The economic value lost from } \\
\text { cultivation activities (Land, Brackish and Sea) }\end{array}$ & $\begin{array}{l}\text { Effect on Production Income Approach, } \\
\text { Residual Rent) / Cost Benefit Analysis }\end{array}$ \\
\hline 3. & $\begin{array}{l}\text { Nilai ekonomi yang hilang dari aktivitas terkait/ The lost } \\
\text { economic value of the related activity }\end{array}$ & Travel Cost Method \\
\hline 4. & $\begin{array}{l}\text { Nilai ekonomi dari kerusakan ekosistem pesisir } \\
\text { (mangrove, terumbu karang dan lamun)/ The economic } \\
\text { value of damage to coastal ecosystems (mangroves, } \\
\text { coral reefs and seagrasses) }\end{array}$ & $\begin{array}{l}\text { Replacement Cost Method / Benefit } \\
\text { Transfer }\end{array}$ \\
\hline
\end{tabular}


Lanjutan Tabel 1/Continue Table 1.

\begin{tabular}{|c|c|c|}
\hline No & $\begin{array}{c}\text { Jenis Nilai Ekonomi yang Hilang/ } \\
\text { Economics Loss }\end{array}$ & $\begin{array}{l}\text { Teknik Analisis Datal } \\
\text { Technique of Data Analysis }\end{array}$ \\
\hline 5. & $\begin{array}{l}\text { Nilai ekonomi yang hilang dari aktivitas pengolahan } \\
\text { perikanan/ The lost economic value of fishery } \\
\text { processing activities }\end{array}$ & $\begin{array}{l}\text { Income Approach, Residual Rent) / } \\
\text { Cost Benefit Analysis }\end{array}$ \\
\hline 6. & $\begin{array}{l}\text { Nilai ekonomi yang hilang dari terganggunya estetika } \\
\text { lingkungan pesisir/ The economic value lost from the } \\
\text { aesthetic disruption of the coastal environment }\end{array}$ & Contingent Valuation Method \\
\hline 7. & $\begin{array}{l}\text { Nilai ekonomi yang hilang dari kerusakan alat produksi } \\
\text { penangkapan (kapal, alat tangkap, dan alat bantu } \\
\text { penangkapan)/ The economic value lost from damage } \\
\text { to the fishing equipment (ships, fishing gear, and fishing } \\
\text { aids) }\end{array}$ & Replacement Cost Method \\
\hline 8. & $\begin{array}{l}\text { Nilai ekonomi yang hilang dari kerusakan sarana } \\
\text { produksi budi daya (Keramba, Tambak dan lainnya)/ } \\
\text { The economic value lost from damage to cultivation } \\
\text { production facilities (keramba, tambak etc) }\end{array}$ & Replacement Cost Method \\
\hline 9. & $\begin{array}{l}\text { Nilai ekonomi yang hilang dari kerusakan sarana } \\
\text { dan prasarana wisata terkait/ The economic value is } \\
\text { lost from the damage of related tourism facilities and } \\
\text { infrastructure. }\end{array}$ & Replacement Cost Method \\
\hline
\end{tabular}

Sumber: Costanza et al. (1997); Nunes et al. (2000); Adrianto (2006)/

Source: Costanza et al. (1997); Nunes et al. (2000); Adrianto (2006)

\section{b. Biaya Pemulihan (Restoration Cost)}

Pemulihan merupakan bagian dari pengendalian pencemaran dan/atau kerusakan lingkungan hidup yang dilaksanakan dalam rangka pelestarian lingkungan hidup. Biaya Restorasi yaitu biaya yang dikeluarkan dalam rangka upaya pemulihan untuk menjadikan lingkungan hidup atau bagian-bagiannya berfungsi kembali sebagaimana semula. Lingkungan hidup yang tercemar dan/ atau rusak harus dipulihkan dan sedapat mungkin kembali seperti keadaan semula, sebelum terjadi pencemaran dan/atau kerusakan lingkungan hidup. Tindakan pemulihan lingkungan hidup ini berlaku bagi lingkungan hidup publik yang menjadi hak dan wewenang pemerintah serta lingkungan masyarakat yang mencakup hak dan wewenang perorangan maupun kelompok orang. Biaya Pemulihan akibat tumpahan minyak dibagi menjadi dua, yaitu: (1) Biaya pembersihan tumpahan minyak pada kawasan pesisir dan laut; (2) Biaya rehabilitasi lingkungan ekosistem (mangrove, terumbu karang dan lamun).

Masing-masing biaya pemulihan dihitung dengan menggunakan pendekatan penghitungan biaya langsung (cost analysis) terkait upaya pemulihan tersebut. Adapun teknik penghitungan pada biaya tersebut dapat dilihat pada Tabel 2 .

\section{c. Biaya Penilaian (Assessment Cost)}

Biaya penilaian pada kajian dampak tumpahan minyak yang dimaksud adalah semua biaya yang dikeluarkan oleh pemangku kepentingan

Tabel 2. Jenis-Jenis Biaya Pemulihan akibat Tumpahan Minyak di Wilayah Pesisir. Table 2. Restoration costs of Oil Spill in Coastal Area.

\begin{tabular}{clc}
\hline No & \multicolumn{1}{c}{ Jenis Biaya Pemulihan/ Restoration Cost } & $\begin{array}{c}\text { Teknik Analisis Data/ } \\
\text { Technique of Data Analysis }\end{array}$ \\
\hline 1. & $\begin{array}{l}\text { Biaya Pembersihan Tumpahan Minyak pada Kawasan } \\
\text { Pesisir dan Laut/ Cost of Oil Cleaning on Coastal Area }\end{array}$ & Cost Analysis \\
2. & $\begin{array}{l}\text { Biaya Rehabilitasi Lingkungan Ekosistem (Mangrove, } \\
\text { Terumbu Karang dan Lamun)/ Cost of Ecosystem } \\
\text { Rehabilitation (Mangrove, Coral Reef, Seagrass) }\end{array}$ & Cost Analysis \\
\hline
\end{tabular}


mulai dari persiapan, proses sampai dengan pelaporan. Sejatinya biaya-biaya tersebut harus mengacu pada standar biaya yang telah ditetapkan dan diakui oleh baik dalam skala nasional maupun internasional. Biaya-biaya tersebut antara lain yaitu: (1) Biaya Persiapan; (2) Biaya Survei; (3) Biaya Monitoring dan Evaluasi; (4) Biaya Pelaporan; (5) Biaya Negosiasi dan Penuntutan, dan; (6) Biaya Administrasi.

Jenis-jenis biaya penilaian yang termasuk ke dalam kajian dampak tumpahan minyak dihitung dengan menggunakan pendekatan biaya langsung terkait pada tahapan yang dilakukan. Teknik penghitungan pada jenis-jenis biaya penilaian dapat dilihat pada Tabel 3.

\section{Penerapan Prinsip Pencemar Berkewajiban Membayar/Application of Polluter Must Pay Principle}

Adanya pencemaran tersebut tentu membawa kerugian yang besar, tidak hanya bagi lingkungan akan tetapi juga manusia yang menggunakan barang dan jasa dari lingkungan tersebut. Oleh karena itu pencemaran harus diatasi dan kerusakan harus direhabilitasi untuk mengembalikan fungsi-fungsi yang hilang. Namun demikian, penanganan pencemaran dan rehabilitasi lingkungan yang rusak membutuhkan biaya yang tidak sedikit. Pertanyaan yang lebih mendasar kemudian, siapa yang bertanggungjawab untuk melakukan penanganan dan rehabilitasi.

Pada UU No 32 Tahun 2009 tentang Perlindungan dan Pengelolaan Lingkungan Hidup telah mengandung prinsip tanggung jawab negara dimana negara harus menjamin pemanfaatan sumber daya yang dapat memberikan manfaat bagi kesejahteraan dan mutu hidup rakyat secara berkelanjutan. Negara dengan demikian juga wajib menyediakan lingkungan hidup yang baik dan sehat. Untuk itu negara memiliki peran yang besar untuk mencegah terjadinya pencemaran dan atau kerusakan lingkungan hidup. Meski tanggung jawab menjadi milik negara, bukan berarti negara menanggung seluruh beban. Negara lebih tepat disebut sebagai pengelola yang menjamin tujuan dalam pemanfaatan sumber daya tercapai. Dalam hal ini terdapat prinsip lain yang melekat pada UU tersebut yaitu percemar membayar (polluter pay principle).

Prinsip pencemar membayar memberi arti bahwa setiap pencemar memiliki kewajiban untuk menanggung biaya yang dibutuhkan untuk penanganan dan pemulihan lingkungan dari dampak lingkungan yang ditimbulkan. Prinsip ini awalnya diadopsi oleh Organization For Economic Co-Operation and Development (OECD) pada tahun 1972 yang mengatur tentang pengalokasian biaya dari pengendalian polusi yang seharusnya ditanggung oleh pencemar (OECD, 1992). Alokasi biaya ini terdiri dari biaya pencegahan dan kontrol terhadap polusi, administrasi penghitungan dampak polusi dan biaya kerusakan yang ditimbulkan. Mereka yang harus bertanggung jawab termasuk dari kejadian yang disengaja, kelalaian dan atau kecelakaan.

Atas dasar di atas, negara tidak sepatutnya menanggung beban pencemaran yang dilakukan oleh suatu pihak. Pencemarlah yang berkewajiban untuk memberikan alokasi pembiayaan mulai dari penilaian, penanggulangan, rehabilitasi sampai dengan dampak ekonomi yang ditimbulkan. Meski demikian, negara juga tidak boleh abai terhadap

Tabel 3. Jenis-jenis Biaya Penilaian Dampak Tumpahan Minyak.

Table 3. Types of Impact Assessment Costs of Oil Spill.

\begin{tabular}{clc} 
No & \multicolumn{1}{c}{$\begin{array}{c}\text { Jenis Biaya Penilaian/ } \\
\text { Type of Assessment Fee }\end{array}$} & $\begin{array}{c}\text { Teknik Analisis Data/ } \\
\text { Data analysis technique }\end{array}$ \\
\hline 1. & Biaya Persiapan/ Preparation Cost & Cost Analysis \\
2. & Biaya Survey/ Survey Cost & Cost Analysis \\
3. & Biaya Monitoring/ Cost Monitoring & Cost Analysis \\
4. & Biaya Evaluasi/ Evaluation Cost & Cost Analysis \\
5. & Biaya Pelaporan/ Reporting Cost & Cost Analysis \\
6. & Biaya Negosiasi dan Penuntutan/ Negotiation and & Cost Analysis \\
\hline
\end{tabular}

Sumber: Data primer, 2016/ Source : Primary Data, 2016 
pencemaran yang terjadi. Tindakan cepat harus segera dilakukan agar dampak kerugian tidak meluas sehingga merugikan banyak pihak. Terlebih dalam kasus tumpahan minyak tuntutan ganti rugi dapat memakan waktu yang panjang. Bahkan kasus Montara yang terjadi pada tahun 2009 belum juga menemui titik terang sampai dengan saat ini (Kamaludin, 2016).

\section{Aplikasi Valuasi Ekonomi dan Penerapan Pencemar Membayar dalam Kasus Tumpahan Minyak}

Kejadian tumpahan minyak beberapa kali terjadi dan diketahui menggunakan pendekatan valuasi ekonomi di dalam penghitungan nilai kerugiannya. Salah satunya adalah kasus tumpahan minyak di Teluk Meksiko tahun 2010. Kejadian yang disebut tumpahan minyak terbesar di Amerika Serikat, menjadikan pengalaman tumpahan minyak tahun 1989 atau yang lebih dikenal dengan Exxon Valdez spill sebagai dasar penghitungan ganti rugi (Roach et al., 2010). Estimasi kerugian diperkirakan mencapai US \$ 40 milyar sampai dengan US \$ 100 milyar dimana minyak tertumpah sebesar 4,9 juta barrel.

Penerapan prinsip pencemar membayar kemudian diterapkan dalam kasus ini dimana Amerika menggunakan Clean Water Act (CWA) dalam pengenaan denda kepada pencemar. Berdasarkan CWA setiap minyak yang tertumpah dapat dikenakan denda sebesar US \$1.100 sampai dengan US \$ 4.300 jika kejadian tumpahan murni akibat kelalaian pengelola. Dengan demikian estimasi total denda yang harus ditanggung oleh pencemar adalah US \$5,4 milyar - US \$ 21 Milyar. Pada kasus ini, pengenaan denda berdasarkan aturan hukum yang berlaku, berada jauh dari nilai estimasi kerugian yang ditimbulkan.

Di Indonesia pendekatan valuasi ekonomi digunakan pada tumpahan minyak di dekat Pantai Cimiring, di sekitar Single Point Mooring Pertamina Refinery Unit (RU) IV Cilacap yang menutup perairan bagian selatan Pulau Nusakambangan tahun 2015. Untuk menghitung dampak lingkungan telah dilakukan valuasi ekonomi oleh Mauludiyah (2016) dengan pendekatan Nilai Ekonomi Total. Metode yang digunakan secara umum adalah benefit transfer yaitu dengan menggunakan hasil penelitian sebelumnya untuk digunakan pada jenis ekosistem yang terdampak. Hasilnya diketahui bahwa kerugian yang diderita akibat tumpahnya 2.500 ton minyak di kawasan Cilacap yang menutupi 21,3 km² adalah sebesar Rp. 1,9 Triliun.

Kendala yang dihadapi oleh pemerintah Indonesia dalam menggunakan valuasi ekonomi terletak pada ketersediaan data dasar yang seringkali absen. Hal ini menyebabkan sukarnya menghitung perubahan manfaat barang dan jasa yang dihasilkan oleh ekosistem. Dampak lanjutan yang ditimbulkan adalah lemahnya materi gugatan kerugian sebagaimana kasus tumpahan minyak di Montara oleh PTT Exploration and Production Company (PTT EP) Australia yang diklaim mencemari perairan Laut Timor. Kejadian yang terjadi pada tahun 2009 tersebut masih belum menemukan kata sepakat sampai dengan saat ini. Bahkan proses negosiasi melaluijalurnon litigasijuga mengalami jalan buntu (deadlock) ${ }^{1}$. Berdasarkan situs resmi PTT EP bahkan menyatakan tidak ada minyak dari kilang Montara yang memasuki wilayah daratan Republik Indonesia (RI) sehingga tidak berdampak atau sangat kecil dampaknya terhadap kerusakan ekosistem pesisir dan laut. Padahal dari sisi pemerintah RI sudah menghitung total kerugian sebesar Rp. 27,4 triliun yang terdiri dari biaya kerusakan lingkungan sebesar Rp. 23 trilun dan biaya pemulihan sebesar 4,4 triliun ${ }^{2}$.

\section{KESIMPULAN DAN IMPLIKASI KEBIJAKAN}

Kejadian tumpahan minyak bisa terjadi sewaktu-waktu dan dimana saja khususnya yang memiliki kedekatan dengan jalur perkapalan dan aktivitas pengeboran minyak. Hal ini menuntut kewaspadaan pemerintah sekaligus kemampuan untuk menanggulangi kejadian yang terjadi secara cepat. Beriringan dengan itu, pemerintah juga harus segera dapat mengidentifikasi dampak yang ditimbulkan, menghitung nilai kerugian atau dampak ekonomi serta sumber pencemaran.

Penghitungan nilai dampak ekonomi
tumpahan minyak dapat dilakukan dengan
pendekatan valuasi ekonomi. Teknik ini dapat
digunakan sebagai standar baku bagi pemerintah
karena penilaian dengan teknik ini memberi
keuntungan yaitu terhitungnya seluruh manfaat

Penghitungan nilai dampak ekonomi tumpahan minyak dapat dilakukan dengan pendekatan valuasi ekonomi. Teknik ini dapat digunakan sebagai standar baku bagi pemerintah keuntungan yaitu terhitungnya seluruh manfaat 
barang dan jasa yang hilang baik yang bersifat ekonomi langsung, ekologi maupun sosial budaya. Secara total nilai dampak ekonomi dihitung dengan memasukkan tiga komponen yaitu biaya kerugian ekonomi yang dikompensasi, biaya rehabilitasi dan biaya administrasi penghitungan kerugian.

Dampak ekonomi yang timbul akibat terjadinya tumpahan minyak tidak sepantasnya menjadi beban negara. Pencemar harus bertanggungjawab baik karena kejadian yang bersifat tidak disengaja, kelalaian atau kecelakaan. Prinsip pencemar membayar juga telah sesuai dengan peraturan perundangan yang berlaku baik secara internasional maupun nasional

\section{UCAPAN TERIMA KASIH}

Penelitian ini terselenggara berkat pembiayaan dari Pusat Penelitian Sosial Ekonomi Kelautan dan Perikanan. Selain itu, penelitian didukung oleh Direktorat Jenderal Pengelolaan Ruang Laut Kementerian Kelautan dan Perikanan. Dukungan akademis dan praktis juga datang dari Dr. Tukul Rameyo Adi, Dr. Akhmad Fachrudin dan Prof. Dr. Sonny Koeshendrajana untuk itu kepada pihak-pihak yang telah berkontribusi dalam pelaksanaan penelitian dan terbitnya tulisan ini baik yang sudah disebutkan maupun belum diucapkan terima kasih.

\section{DAFTAR PUSTAKA}

Adrianto, L. 2006. Sinopsis Pengenalan Konsep dan Metodologi Valuasi Ekonomi Sumber daya Pesisir dan Laut. PKSPL-IPB. Bogor.

Badan Informasi Geospasial [BIG]. 2014. Indonesia Memiliki 13.466 Pulau yang Terdaftar dan Berkoordinat. Badan Informasi Geospasial. http://www.bakosurtanal.go.id/berita-surta/show/ indonesia-memiliki-13-466-pulau-yang-terdaftar-dan-berkoordinat. Diakses tanggal 14 Maret 2017.

Bengen, D. G. 2004. Sinopsis Ekosistem dan Sumber daya Alam Pesisir dan Laut Serta Prinsip Pengelolaannya. Pusat Kajian Sumber daya Pesisir dan Lautan. IPB. Bogor.

Claridge, D. dan J. Burnett. 1993. Mangrove in Focus. Wet Paper Marine Education, Ashmore.

Costanza, R., R. de Groot, S. Farberk, M. Grasso, B. Hannon, K. Limburg, S. Naeem, R. V. O'Neill, J. Paruelo, R. G. Raskin, P. Sutton and M. van den Belt.1997. The Value Of The World's Ecosystem Services and Natural Capital. Nature Vol 387 (1997).
De Groot, R.S., M. A. Wilson and R. M. J. Boumans. 2002. A Typology for the classification, description and valuation of ecosystem functions, goods, and services. Ecological Economics 41 (p.393-408).

Elo, S. and H. Kyngas. 2007. The qualitative content analysis process. Journal of Advanced Nursing 62(1), 107-115 doi: 10.1111/j.13652648.2007.04569.x.

Faikoh, E. N., D. E. Yuliana, S. Suhendriani dan H.Q. Aini. 2013. Studi Daya Antibakteri Ekstrak Karang Lunak (Geodia Sp.) Segar Terhadap Bakteri Escherechia coli dan Vibrio Parahaemolyticus Serta Kandungan Senyawa Aktifnya. Jurnal Teknologi Pertanian Vol. 14 No. 3 [Desember 2013] 201-208. Universitas Brawijaya. Malang.

Helut, S. 2005. Tumpahan Minyak di Perairan Ambon Meluas. Liputan6.com. http://news.liputan6.com/ read/107719/tumpahan-minyak-di-perairan-ambon-meluas.

JICA-Dephub. 2002. The Study for The Maritime Safety Development Plan in Republic of Indonesia, Jakarta.

Kamaludin, A. 2016. Luhut Desak Australia Selesaikan Pencemaran Minyak Montara. Katadata.com. http://katadata.co.id/berita/2016/12/02/luhut-desak-australia-selesaikan-kasus-pencemaran-minyak-montara.

Koeshendrajana S, A. Ramadhan, F.N. Priyatna, E. Reswati, Hikmah, A. Zamroni, R. Pramoda, R. Triyanti, R. Aprilian, M. Firdaus, Mira, S. Saptanto, Lindawati, I. Muliawan, A. Desfamita. 2015. Pemetaan Sosial Ekonomi Sumberdaya Pesisir Berbasis Kawasan. Balai Besar Sosial Ekonomi Kelautan dan Perikanan. Jakarta.

Kay, R. and J. Alder. 1999. Coastal Planning and Management. E \& FN Spon. London

Kementerian Energi dan Sumber Daya Mineral (KESDM). 2016. Statistik Migas Kementerian Energi dan Sumber Daya Mineral. http://statistik.migas.esdm. go.id/index.php?r=dataTumpahanMinyak/index\&DataTumpahanMinyak_sort=Tahun\#Lubis, S. 2010. Potensi Minyak dan Gas Bumi di Indonesia, Slide Presentasi Lokakarya Nasional Pengelolaan Jasa Kelautan dan Kemaritiman, 19 Juni 2010. Jakarta.

Lubis, S. 2010. Potensi Minyak dan Gas Bumi di Indonesia, Slide Presentasi Lokakarya Nasional Pengelolaan Jasa Kelautan dan Kemaritiman, 19 Juni 2010. Jakarta.

Mauludiyah. 2016. Valuasi Ekonomi Dampak Lingkungan Akibat Tumpahan Minyak di Perairan Cilacap. Marjan Vol 1 No.1 tahun 2015. Universitas Islam Negeri Sunan Ampel. Surabaya. ISSN No. 2460-8106. 
Nilwan, I. Nahib, Y. Suwarno dan M. I. Cornelia . 2003. Spesifikasi Teknis Penyusunan Neraca Dan Valuasi Ekonomi Sumber daya Alam Pesisir Dan Lautan. Pusat Survei Sumber daya Alam Laut Bakosurtanal. Bogor

Nunes, P. A. L. D., J. C. J. M. van den Bergh and P. Nijkamp. 2000. Ecological Economic AnalysisEconomic Analysis and Valuation of Biodiversity and Valuation of Biodiversity.

Ofiara, D.D. and J.J. Seneca. 2001. Economic Losses from Marine Pollution : A Hand Book for Assessment. Island Press. Washington D.C.

Organization For Economic Co-Operation and Development [OECD]. 1992. The Polluter-Pays Principle OECD Analyses and Recommendations. Organisation For Economic Co-Operation and Development. Paris.

Pardosi, A.S. 2016. Potensi dan Prospek Indonesia Menuju Poros Maritim. eJournal IImu Hubungan Internasional, 2016, 4 (1) 017-026 ISSN 2477-2623. Universitas Mulawarman.

Pearce, D., G. Atkinson and S. Mouratou. 2006. Cost-Benefit Analysis and The Environment: Recent Developments. Organisation for Economic Cooperation and Development. OECD Publishing. France

Roach, B., J. M. Harris and A. Williamson. 2010. The Gulf Oil Spill: Economics and Policy Issues. Global Development And Environment Institute. Tufts University. Medford.

Supriharyono. 2007. Pengelolaan Ekosistem Terumbu Karang, PT. Djambatan. Jakarta. Services and Natural Capital. Nature Vol 38715 May 1997.

United Nation [UN]. 1982. United nations Convention on the Law of the Sea, 1982, Article 1 (4).

\section{Peraturan dan Perundang-undangan}

Republik Indonesia. 2009. Undang-Undang Nomor 32 Tahun 2009 tentang Perlindungan dan Pengelolaan Lingkungan Hidup. Lembaran Negara Republik Indonesia Nomor 5059. Jakarta.

Peraturan Presiden Republik Indonesia [Perpres RI]. 2006. Peraturan Presiden Republik Indonesia Nomor 109 Tahun 2006 Tentang Penanggulangan Keadaan Darurat Tumpahan Minyak Di Laut. 